How to Cite

Payadnya, I. P. A. A., \& Atmaja, I. M. D. (2020). Implementing "what-if" learning strategy to improve high order thinking skills (HOTS) of students in statistics method I subject. International Journal of Physics \& Mathematics,

3(1), 6-12. https://doi.org/10.31295/ijpm.v3n1.115

\title{
Implementing "What-If" Learning Strategy to Improve High Order Thinking Skills (HOTS) of Students in Statistics Method I Subject
}

\author{
I Putu Ade Andre Payadnya \\ Universitas Mahasaraswati Denpasar, Denpasar, Indonesia \\ Corresponding authoremail: adeandre@unmas.ac.id \\ I Made Dharma Atmaja \\ Universitas Mahasaraswati Denpasar, Denpasar, Indonesia \\ Email: dharma.atmaja07@unmas.ac.id
}

\begin{abstract}
This study aimed to improve students' high order thinking skills (HOTS) specifically in Statistics Method I subject by implementing the "what-if" learning strategy. This research is a two-cycle classroom action research. The subjects of this study were as many as 16 students in the 2018/2019 academic year as semester IIA students from the Mathematics Education Study Program, Faculty of Teacher Training and Education, Universitas Mahasaraswati Denpasar. Techniques for collecting data used interviews, observations, and essay tests. This research used two methods for data analysis, i.e. qualitative analysis and quantitative analysis. Qualitative analysis uses methods such as mathematical models and analyses that are performed by conducting explanations restricted to data management techniques. Moreover, the quantitative analysis used a simple level calculation to determine the average value and completeness level of students' high order thinking skills. The study results showed an increase in the students' high order thinking skills from the first cycle to the second cycle. The average score of the students' high order thinking skills only exceeded 71.125 with completeness level 62.5 percent in the first cycle. In the second cycle, the average score of students' high order thinking skills is 84,125 with completeness level touching 87.5 percent. The increase in average score from the first cycle to the second cycle is $18,27 \%$ and the increase in students' completeness level is 40\%. This study concluded that applying the "what-if" learning strategy in the Statistics Method I subject could improve the high order thinking skills of students.

Keywords---"what-if" learning strategies, high order thinking skills, mathematical, models, statistics method I.
\end{abstract}

\section{Introduction}

21st-century mathematics learning emphasizes the importance of developing four abilities that include creativity, critical thinking ability, collaboration, and communication skills (Yustinaningrum, 2019). These abilities must be integrated and implemented in mathematics learning in schools. A teacher as an intermediary for delivering information to students certainly has an important role in making it successful (Purbaningrum, 2017). The teacher acts as a facilitator who facilitates students and creates a student-centered learning activity.

According to Badjeber \& Fatimah (2018), mathematics is a science that aims to train students to think critically, systematically, logically, analytically, and creatively as well as having effective willpower. The ability to think critically, logically, reflective, metacognitive and creative is a higher-order thinking skill or Higher Order Thinking Skills (King et al., 2012). High Order Thinking Skills is a process of thinking of students in a higher cognitive level that is developed from various concepts and methods of cognitive and learning taxonomies such as the method of problem-solving, bloom taxonomy, and the taxonomy of learning, teaching, and assessment (Saputra, 2016; Tumbaco et al., 2019). These high order thinking skills include problem-solving skills, creative thinking skills, critical thinking, argumentative abilities, and decision-making abilities. The main purpose of high order thinking skills is how to improve students' thinking skills at a higher level, especially those related to the ability to think

ISSN 2632-9417

Received August 18, 2019/Accepted November 30, 2019/Published January 01, 2020 
critically in receiving various types of information, think creatively in solving a problem using the knowledge possessed and make decisions in situations that are complex (Saputra, 2016). However, the reality is that the development of mathematical high order thinking skills is currently not optimal.

Based on the 2018 Indonesia National Exam press conference the junior high school average mathematics national exam score in 2016 was 61.33, in 2017 it dropped to 52.69 and in 2018 it dropped sharply to 31.38 (Kemdikbud, 2018). The Minister of Education and Culture stated that the 2018 UN score reduction which was quite drastic was among others caused by an increase in HOTS questions reaching $10 \%$ to $15 \%$. Besides, on a broader scale, based on the results of PISA (OECD, 2015), conducted every three years from 2000 to 2015 for students under 15 years, data obtained that Indonesian students always occupy the top 65 positions or can be said to be the lowest in PISA (Kemdikbud, 2016). Some of this data shows the lack of mathematical thinking skills possessed by students in Indonesia. This is a significant problem considering the ability to think mathematically is the basis for learning mathematics.

Many concepts in mathematics require higher-order thinking skills. One material that requires sufficient high order thinking skills is Statistical Method I (Suryana, 2012; Widana et al., 2018). Statistical concepts have many functions in various fields (Abdullah \& Suhartini, 2017; Suarsana et al., 2018). In the field of education, statistical concepts are used to examine the success of learning, the effectiveness of the learning model, the validity of the instruments, etc. Statistical Method I is an important statistical material for students to learn the basics of research statistics which will greatly assist students in studying research statistics for their final assignments. Statistical Method I do not only learn and apply formulas but also understands the essence of the statistical concept itself and applies good thinking skills to be able to learn and solve various statistical problems.

The results of observations conducted by the researchers on class IIA Mathematics Education Study Program at Mahasaraswati University Denpasar showed that students were still terribly troublesome to demonstrate high order thinking skills. The lacked students' high order thinking skills are mainly seen in Statistics Method 1. Students tend to still perceive the thought of statistics on a basic and procedural concept while not having the ability to deeply analyze the non-routine issues given. During this case, Statistical Method I subject focuses on the fundamentals of statistics and its development towards analysis statistics. Characteristics of class IIA show that students don't seem to be ready to perceive the concept and focus on memorizing and applying formulas.

The lacked high order thinking skills in the Statistical Method I subject requires an appropriate solution. The arrangement should be possible by applying the correct learning model and methodology. One of the appropriate learning strategies used to improve students' high order thinking skills is the "What-If" learning strategy. "What-If" learning strategy is a learning strategy that uses a series of questions in learning that are developed from the "WhatIf-Not" strategy. The "What-If-Not" learning strategy was first put forward by Song et al., (2007). Song et al. (2007), classify the level of problem posing on two levels, which are "accepting problems" and "challenging problems". At the level of "challenging problems", new questions can arise from these problems. The "What-If" learning strategy was developed by Payadnya et al. (2016), by giving wider space to the possibility of generating new ideas and developing thinking skills through "not" omission. The emergence of new ideas from these problems will improve students' high order thinking skills.

Research conducted by Payadnya et al. (2016), found that the "What-If" learning strategy could improve students' critical thinking and divergence in solving open-ended mathematical problems. Through "what-if" based learning students can improve their abilities and develop their thinking to be able to find various possible solutions to a problem. In addition, research on the implementation of the "What-If-Not" learning strategy has been carried out by Hussen (2016), who found that the use of the "What-If-Not" strategy is an effective strategy in problem posing to increase creativity. This strategy helps students to ask fluency and variety of questions so that the questions posed by students can allow these questions to be unusual questions raised by other students (originality).

Based on the problems described above, the researchers deemed it necessary to conduct research on "Implementing "What-If” Learning Strategy to Improve High Order Thinking Skills (HOTS) of Students in Statistics Method I". The purpose of this study was to determine and describe the improvement of high order thinking skills of class IIA students of Mathematics Education Study Program, Mahasaraswati University Denpasar in Statistical Method I subjects. This research will be useful to help students improve their high order thinking skills and as an alternative to lecturer in carrying out classroom learning activities. 


\section{Method}

\section{Research Design}

This research uses a classroom action research design with Kurt and Lewin models. This research was conducted in two cycles with each cycle containing three meetings with details twice for learning and once for the post-test. Each cycle consists of four stages: (1) planning, (2) action, (3) observation, (4) reflection of Mulia \& Suwarno (2016).

\section{Location and Research Subject}

This research location was Mathematics Education Study Program Universitas Mahasaraswati Denpasar. The subjects in this research were the students of class IIA of the Mathematics Education Study Program totaling 16 students. Subjects were chosen due to significant problems in terms of high order thinking skills in Statistics Methods I.

\section{Data Collection Methods}

In this study data collection was done using several ways as follows:

1) A test used to measure the improvement of the ability level of class IIA students in Mathematics Education Study Program, Mahasaraswati University Denpasar. The test used in this study was an essay test specifically arranged for measuring the students' critical thinking skills. This test consists of 4 to 5 problems related to Statistical Method I materials (validity, reliability, normality, homogeneity). The test used in this study was validated by using the content validity test (expert test) involving two experts who were lecturers of mathematics education specializing in research statistics. The results of the content validity test show the instrument of Cycle I Post-Test and Cycle II Post-Test instruments have a validity value of 1 or very high.

2) Observations were carried out by observing directly in each activity. This research used unstructured type observations.

3) Documentation of data originating from documents such as written documents in the form of high order thinking skills, learning motivation, literature books that are closely related to research object information.

4) Interviews conducted with several students and teacher-related to this research. This research used unstructured type interviews.

\section{Data Analysis Technique}

This study used 2 data analysis techniques namely qualitative analysis and quantitative analysis. Qualitative analysis in this study used models such as mathematical models and analyses that are carried out limited to data management techniques by performing descriptions. Whereas, quantitative analysis is carried out by measuring learning outcomes in the form of average scores and percentages and also students' completeness level using a simple level of calculation. The simple level calculation using a formula such as follows:

1. Students' high order thinking skills average scores:

$$
\begin{aligned}
& \frac{\mathrm{X}=\frac{\sum X}{N}}{\text { Information: }} \\
& \overline{\mathrm{X}} \quad: \text { average scores } \\
& \sum X \quad: \text { sum of students' score } \\
& N \quad: \text { a total of students }
\end{aligned}
$$

2. Students' learning completeness:

$$
\begin{aligned}
& K B=\frac{T}{N} \times 100 \% \\
& \text { Information: } \\
& \mathrm{KB} \quad: \text { learning completeness } \\
& \mathrm{T} \quad: \text { number of students who reach/pass the learning completeness level } \\
& \mathrm{N} \quad: \text { a total of students }
\end{aligned}
$$

The minimum average determined in this research is 70 (B) with a minimum learning completeness level is $80 \%$. 


\section{Results and Discussion}

Results

In the initial cycle, the average score of students' high order thinking skills was 68 with the student learning completeness $43,75 \%$ which was still less from the minimum desired level of 70 . This shows that there are things that need to be improved in the learning process. Then, in cycle I, the learning process was carried out using video media and LKM that presented "What-If" questions. Changes seen in the development of students' high order thinking skills from 68 to 71,125 on average with learning completeness reached $62.5 \%$. However, this value does not meet the minimum completeness goal.

To accommodate this, the researcher noticed that in the discussion of "What - If" questions, the discussions that took place between students were less successful, where they were conducted only in one direction from the lecturer to the students. "What - if" questions are only posed in the LKM as the core in this study and asked the students by the lecturer. It leads the "what-if" issue to be absent.

Researchers have taken the step to resolve the limitations in cycle I to be strengthened in cycle II by incorporating points in student LKMs which allow students to compile their own "What - If" questions and send them to other classes. This gave rise to a competitive atmosphere among students so that students could better understand the "What-If" questions and make full use of their thinking power to organize different "What-If" questions for other classes. The effective method of thinking makes the critical thinking skills of students more advanced. Evident from the results obtained by students at the end of the second cycle where the average score of students' high order thinking skills reached 84,125 with learning completeness reaching 87.5\%. This shows that the Statistical Method I subject learning by using the "What-If" learning strategy proved effective in improving students' high order thinking skills.

Table 1

Data Tabulation Regarding Student Score Improvement

\begin{tabular}{llll}
\hline Aspect & Initial Cycle & Cycle I & Cycle II \\
& Initial Test & Post-test 1 & Post-test 2 \\
\hline Mean & 68 & 71.125 & 84.125 \\
Students' learning completeness & $43.75 \%$ & $62.5 \%$ & $87.5 \%$ \\
\hline
\end{tabular}

Students said from the interview that learning strategy for "What - If" is very interesting and fun. Students indicated that at first the confusing question of "What-If" but with the researcher's guidance they begin to understand and begin to consider that the "What-If" issue is difficult and allow them to develop their critical thinking skills.

\section{Discussion}

The researcher's initial description after the initial test and evaluation of the IIA students of the Universitas Mahasaraswati Denpasar Mathematics Education Study Program is that most students do not have a strong basis in statistical data. Students convey statistics more as content based on calculations, memorization and equation application.

a) Cycle I

\section{Planning}

For the first and second meetings, researchers prepared Weekly Learning Plans (RPM) and Student Worksheets (LKM) between Statistical Method I. Researchers ' content in this first cycle was to test the validity and quality of the research tools. The researchers ' RPM and LKM use the "What-If" problem theory in it, which is the cornerstone of this work to develop the high order thinking skills of students. In addition to collecting RPM and LKM, researchers also collected learning clips that were introduced at the start as a warm-up to provide students with the basics of statistics. Learning videos are compiled using Microsoft PowerPoint applications which are then recorded on the screen by using a special screen recording application. 
Action

Played learning videos include the basic concepts of statistics so that it is very useful for students to access the research statistics content that is commonly discussed in Course 1 of Statistical Method I. After the learning video has been shown, researchers continue the main material by having students into small groups of 3-5 people and then share the LKM with students in each group. The researcher began the initial material description and then led the students to work on the prepared LKM. Students learned the concept of validity in the first two meetings and then gave a set of data obtained from instrument testing which is the students had to determine the validity and reliability of the instrument. The LKM contains "What - If" questions that students have to answer based on their respective experiences and beliefs. The next task is to present their work on LKM to the students and start the discussion with other teams. The researcher also created verbally "What - If" questions for students at the end of the learning activity to further enhance the thinking skills of students. This activity took place for two meetings and at the third meeting, the researchers gave a post-test to measure the improvement of students' high order thinking skills.

\section{Observation}

Cycle I tasks usually run well with students who seem to concentrate on activity reading. Researchers can enhance focus and student interest in the presented content with the aid of learning videos. While many students are puzzled, student answers to the "What - If" question are quite optimistic. Nonetheless, intense debates that were supposed to be held by students in the first phase of learning activity do not occur because the question "What - If" is only posed in the LKM and conveyed orally by the lecturer. This makes the learning activity ran in one direction, especially in the discussion of "What-If" questions which are expected to trigger students in developing their high order thinking skills.

\section{Reflection}

The reflective focus of the first process is the lack of active discussion by students of the "What-If" issue as the questions submitted are still in one direction, from the LKM or the researcher to the students. The researchers ' change was to update the LKM template, which also guided students to compile their own "What - If" questions in each class that would be sent to other groups later. This is supposed to intensify the debate, and as it provides an intellectual tournament environment for students to further improve their high order thinking skills, students will become more involved.

\section{b) Cycle II}

\section{Planning Revision}

From the reflection of the cycle I linked to the one-way conversation that took place on the "What-If" issue, the researcher made changes that centered on LKM which included encouragement for students to create their own "What - If" questions so that there was a better discussion between students.

\section{Action}

The action given in this second cycle is nearly the same as the first cycle. The lecturer will provide introductory material and then disperse the LKM to students in each class to be addressed. In addition to answering the "What If" questions, however, the distinction is in the LKM, students are also asked to formulate their own "What-If" questions that will be sent to other classes. The materials in the second cycle were the test of normality and homogeneity of variance. In this material, students are introduced to the concepts of data normality and homogeneity, not only to know the formula but also to understand the significance and characteristics of normal and homogeneous data and to use this interpretation in real research. After the LKM's implementation exercises take place, students are asked to present their team's work results and submit questions to other classes as well as "WhatIf." In this case, the conversation was very interesting and the students seemed to be involved. At the end of the second period, students were again given a post-test question to measure the progress in their high order thinking skills.

\section{Observation}

The second cycle went very well. Changes in LKM that provide opportunities for students to compile and send their own "What - If" questions to other classes invoke an environment of intergroup rivalry. It makes the debates that take place between students easier and the students compete to be able to think more critically to be able to answer a variety of questions to other classes. This helps students to improve their ability to think critically. 
Reflection

Generally, learning activity took place very well, consistently and successfully in the second cycle. Students should answer, understand and compile "What-If" questions to further improve their high order thinking skills.

\section{Conclusion}

The conclusions obtained in this study are as follows: 1) Significant increase occurred in the score of high order thinking skills of class IIA students of Mathematics Education Program at Universitas Mahasaraswati Denpasar in Statistical Method I subject after being taught with "What-If" learning strategies with details of achievements in the first cycle with details of average score is 71,125 followed by learning completeness only reached $62.5 \%$, and in the second cycle researcher get that high order thinking skills of students experienced an increase in average reaching 84.125 and in learning completeness by reaching 87.5\%,2) Application of "What-If" learning strategies in class IIA Mathematics Education Study Program at Universitas Mahasaraswati Denpasar in Statistical Method I went effectively and can improve students' high order thinking skills.

\section{Suggestion}

The suggestions from this research are as follows: 1) Develop "What-If" learning strategies in terms of materials, abilities, and variations; 2) Develop modules and training platforms focused on "What-If" learning strategy; 3) "What-If" learning strategy needs to be applied in other forms of further growth research.

\section{Acknowledgments}

This work was supported by the Research Fund provided by Lembaga Penelitian dan Pengabdian kepada Masyarakat (Research and Community Service Institution) of Universitas Mahasaraswati Denpasar.

\section{References}

Abdullah, A. A., \& Suhartini, S. (2017). Meningkatkan Kemampuan Berpikir Kritis Melalui Pembelajaran Statistika Berbasis Pendidikan Politik Di Lingkungan Sekolah. Jurnal Gantang, 2(1), 1-9. https://doi.org/10.31629/jg.v2i1.63

Badjeber, R., \& Fatimah, S. (2015). Peningkatan kemampuan koneksi matematis siswa SMP melalui pembelajaran inkuiri model alberta. Jurnal Pengajaran MIPA, 20(1), 18-26.

Hussen, S. (2016). Penerapan Strategi "What-If-Not" dalam Pembelajaran Model Problem Posing untuk Meningkatkan Kreativitas Siswa Pada Bangun Ruang Sisi Datar Kelas VIII D SMPN 17 Malang. DISERTASI dan TESIS Program Pascasarjana UM.

Kemdikbud. (2016). Peringkat dan Capaian PISA Indonesia Mengalami Peningkatan. (Online), (https:/www.kemdikbud.go.id/main/blog/2016/12/peringkat-dan-capaian-pisa-indonesia-mengalamipeningkatan), diakses 1 Oktober 2019

Kemdikbud. (2018). Konferensi Pers UN $2018 \quad$ Jenjang $\quad$ SMP. (https://kemdikbud.go.id/main/files/download/9c7fdf36a39328d), Accessed 1 Oktober 2019

King, F. J., Goodson, L., \& Rohani, F. (2012). High Order Thinking Skills. A Publication of the educational Service Program. Center for the Advancement of Learning and Assessment.

Mulia, D. S., \& Suwarno, S. (2016). PTK (penelitian tindakan kelas) dengan pembelajaran berbasis kearifan lokal dan penulisan artikel ilmiah di sd negeri kalisube, banyumas. khazanah pendidikan, 9(2).

OECD. (2016). PISA 2015 Result in Focus. Paris: OECD Publishing

Payadnya, I. P. A. A., Suparta, I. N., \& Suweken, G. (2016, August). Pengembangan Desain Pembelajaran Berbantuan Pertanyaan What-If dalam Upaya Meningkatkan Kemampuan Siswa Menangani Permasalahan Matematika Terbuka. In Prosiding Seminar Nasional MIPA.

Purbaningrum, K. A. (2017). Kemampuan berpikir tingkat tinggi siswa SMP dalam pemecahan masalah matematika ditinjau dari gaya belajar.JPPM (Jurnal Penelitian dan Pembelajaran Matematika), 10(2). http://dx.doi.org/10.30870/jppm.v10i2.2029

Saputra, H. (2016). Pengembangan mutu pendidikan menuju era global: Penguatan mutu pembelajaran dengan penerapan hots (high order thinking skills). Smile's. 
Song, S., Yim, J., Shin, E., \& Lee, H. (2007). Posing problems with use the 'what if not?'strategy in NIM game. In Proceedings of the 31st Conference of the International Group for the Psychology of Mathematics Education (Vol. 4, pp. 193-200).

Suarsana, I. M., Mahayukti, G. A., Sudarma, I. K., \& Yoga, I. N. B. A. (2018). Development of interactive mathematics learning media on statistics topic for hearing-impaired student. International Research Journal of Engineering, IT \& Scientific Research, 4(6), 55-66. https://doi.org/10.21744/irjeis.v4n6.377

Suryana, A. (2012). Kemampuan Berpikir Matematis Tingkat Lanjut (Advanced Mathematical Thinking) dalam Mata Kuliah Statistika Matematika 1. Yogyakarta: UNY.

Tumbaco, D. E. S., Albán, W. E. M., Ruperti, M. J. B., \& Palacios, D. E. P. (2019). Methodological strategies used in the learning of mathematics in the 8th year of EGB. International Journal of Social Sciences and Humanities, 3(3), 90-98. https://doi.org/10.29332/ijssh.v3n3.362

Widana, I. W., Parwata, I. M. Y., Parmithi, N. N., Jayantika, I. G. A. T., Sukendra, K., \& Sumandya, I. W. (2018). Higher order thinking skills assessment towards critical thinking on mathematics lesson. International Journal of Social Sciences and Humanities, 2(1), 24-32. https://doi.org/10.29332/ijssh.v2n1.74

Yustinaningrum, B. (2019). Model pembelajaran matematika abad 21 (kajian model project based learning). Jurnal Sinektik, 2(1), 48-63. http://dx.doi.org/10.33061/js.v2i1.3019 